\title{
Analysis on the Application of Punitive Compensation Clauses in the Field of Food Safety
}

\author{
Chenglong $\mathrm{Xu}$ \\ China Jiliang University \\ Hangzhou, China
}

\begin{abstract}
It is very important to establish and improve the punitive damages system in the field of food safety. The punitive damages clause is clearly stipulated in the Food Safety Law. In the application of the punitive damages clause in the food safety field, there is a debate on the operator's review obligation, that is, operator's review obligation should be formal or substantive; the theoretical and practical circles have disputes over whether the application of punitive damages requires actual damage, and according to the analysis of the cases finding that the "loss of three times" clause applies less in practice. It is believed that the operator's ability to control food safety is weak, so the operator's review obligation is formal review rather than substantive review. The application of the punitive damages clause does not need to be based on the actual damage and when awarding the amount, the judge is given a certain discretion is recommended.
\end{abstract}

Keywords-punitive damages; form review; actual damage; discretionary power

\section{INTRODUCTION}

"The country is based on the people, the people take food as the heaven, and the food is the first." The establishment of a punitive damages system in the food safety field is crucial. China's Food Safety Law clearly stipulates punitive damages, but by analyzing cases and doctrines, there is still theoretical or practical controversy in application of the punitive damages clause of the Food Safety Law, leading to different judgments in the same case. This article uses punitive damages as a study objects and explore the problems in the application of punitive claims.

\section{OPERATORS SHOULD PERFORM FORMAL REVIEW OBLIGATIONS}

Through the combing of the punitive damages cases in the field of food safety application, it is found that the focus of the cases in practice is mainly whether the operators have fulfilled a reasonable review obligation. For example, in the case of Yang's online shopping contract dispute with a certain trading company, the court held that the date of issuance of the inspection and quarantine certificate of the inbound goods provided by a certain commerce company does not correspond to the 41 boxes of products involved. The first-instance judgment identified 41 boxes. The products involved are products that do not meet the food safety standards. It is not improper for a certain commerce and trade company to fulfill its statutory obligations for inspection. ${ }^{1}$ In the case of a certain trading company and a certain sales contract dispute, the court held that: "Some Trade Co., Ltd. has provided the health certificate, the import goods declaration form, the supplier's subject qualification and the authorization permit document, etc. The evidence forms a chain of evidence to verify each other, and it can be concluded that a certain trading company has proved the legal source of the products involved, and fulfills the statutory purchase inspection obligation." 2 In such cases, whether the operators have shouldered reasonable review obligations is obvious. However, in the case of a certain trading company and a certain online shopping contract dispute, the operator's review obligation should be to "pay attention to the good manager's duty" or "general duty of care". The court held that "the product using the shortening as an ingredient does not necessarily contain hydrogenated oil. The product ingredients contained shortening, but the evidence submitted by the plaintiff could not fully confirm that the shortening used in the case product contained hydrogenated oil. On the contrary, according to the "Test Report" of the Penny Test Group Co., Ltd. submitted by the defendant company, it is proved that the trans-fatty acids in the same batch of products are not detected $(<0.05 \%)$. According to this, according to the evidence stated and submitted by the parties, the plaintiff claimed that the product involved in the violation of the "Food Safety National Standards for Prepackaged Food Nutrition Labelling" (gb28050-2011) lacked sufficient factual basis and its claim should not be adopted. ${ }^{3}$

It is believed that the operator's reasonable review obligation is "general duty of care", not "the duty of good manager". The review of the goods by the operator should be a formal review rather than a substantive review. It is assumed that the operator should be aware of the law because the law is open. Therefore, the operator should fulfill the obligations of the operator as stipulated in the legal norms (including the mandatory provisions of food safety standards), including, when purchasing goods, the producer's

See Suzhou Intermediate People's Court (2017) Su 05 Min Zhong 4817 Civil Judgment.

2 See the Civil Judgment of Guangzhou Intermediate People's Court (2017) Guangdong 01 Minquan 10043.

See the Civil Judgment of Guangzhou Intermediate People's Court (2017) Guangdong 01 Minquan 9301. 
business license, the scope of the licensed production, and the qualification certificates, production dates, product identifications, etc. For imported products, it is also necessary to review the import customs quarantine certificate and whether the product has a Chinese logo. The operator should review the commodity in a formal manner. If the operator is subject to the substantive review obligation, the operator is over-stressed and this is inconsistent with the current situation of the existence of small shops in China.

\section{THE APPLICATION OF THE PUNITIVE DAMAGES Clause Does Not NeEd to Be Based on the OCCURRENCE OF ACTUAL DAMAGE}

Article 148-paragraph 2, of the Food Safety Law causes controversy both in practice and in the theoretical world. In judicial practice, some courts have combined the provisions of Article 47 of the Law of the People's Republic of China on Tort Liability for punitive damages: the application of the punitive damages system in the Food Safety Law must be based on the occurrence of actual damages. For example, in the second-instance judgment of Liu $\mathrm{Xx}$ and a certain supermarket chain company, a certain supermarket chain company, a certain store sales contract dispute, the court held that "the appellant has not been damaged by the purchase or consumption of jelly, so the appeal request for ten times compensation is not supported by this court." ${ }^{4}$ In the secondinstance judgment of $\mathrm{X}$ and $\mathrm{Y}$ trade companies ${ }^{5}$, although the appellant did not provide evidence to prove his personal injury and his claim for payment of ten times, the price of the payment still received the support of the court of second instance. In terms of academics, there is a dispute as to whether the application of punitive damages requires actual damage. Some scholars believe that punitive damages are premised on the existence of filling compensation. Only when they meet the requirements of the compensatory compensation, can they request punitive damages. In principle, the victims cannot separately request punitive damages. ${ }^{6}$ Some scholars also believe that the compensation for filling damages emphasizes compensation and relief for victims, and should be based on the occurrence of actual damage, but punitive damages are not based on the occurrence of actual damage. ${ }^{7}$ Some scholars believe that the punitive damages stipulated in this article (Article 148 of the Food Safety Law) may not be claimed only if the consumer has actual damage, even if the consumer has not eaten after purchasing the food that does not meet the food safety standards. They can still ask the producers and operators to pay 10 times the compensation. ${ }^{8}$ The damage

See the Civil Judgment of Taiyuan Intermediate People's Court (2017) Jin 01 Min Zhong 2039.

See Zhengzhou Intermediate People's Court (2018) Yu 01 Min Zhong 7887 Civil Judgment.

See Wang Liming, Zhou Youjun, Gao Shengping: Research on Difficulties in Tort Liability Law, China Legal Publishing House, 2012, p. 409.

See Gao Shengping, "Legislative Purposes and Rules Design of the Food Safety Punitive Compensation System", Jurists, No. 6, 2013, pp. 59-60.

See the Legal Affairs Committee of the Standing Committee of the National People's Congress, and the editor of Xin Chunying: caused by the food purchased by the consumer is not necessary to the application of the punitive damages system. In other words, as long as the producer produces food that does not meet the food safety standards or the seller sells the food which is not in compliance with food safety standards. The food, then whether or not the damage occurred, will be subject to punitive damages. ${ }^{9}$ Since the punitive damages system is not a native system, but an exotic product, it is a product of legal transplantation. Therefore, if you want to understand the components of punitive damages, you need to use a comparative analysis method.

China's punitive damages system learned from the United States because its punitive damages system is extremely developed. ${ }^{10}$ Therefore, this article takes the US punitive damages system as the reference. There is always debate in the United States as to whether actual damage is one of the elements that constitutes punitive damages. Most courts in the United States believe that unless the plaintiff can prove the actual damage suffered, the plaintiff cannot request punitive damages. However, some state courts believe that as long as the plaintiff can prove that the defendant violated the statutory obligations. Some states have adopted an eclectic attitude: they do not demand that the plaintiff prove that they have suffered actual damage, and that they directly request punitive damages for insulting or defaming cases. ${ }^{11}$ In order to unify the application of state laws, the United States has enacted the Model Law on Punitive Compensation. The Act a (1) stipulates that the defendant's damage to the plaintiff can only be punishable by the defendant for punitive damages under the law if the state imposes punitive damages on the damage. In the application of punitive damages, the victim must first prove that the actual damage has occurred and that the damage is caused by the defendant's actions. ${ }^{12}$

It is believed that the application of the punitive damages provisions in the second paragraph of Article 148 of the Food Safety Law does not need to be based on the occurrence of actual damages, but is an independent claim, not taking compensation claim as the premise. The reasons are as follows from the academic analysis:

- Article 47 of the Law of the People's Republic of China on Tort Liability clearly stipulates that the application of punitive damages in product liability must be based on actual damage. However, Article 148 of the Food Safety Law does not include the occurrence of actual damage as a precondition for the application of punitive damages. Food is a product of a broad sense. Therefore, punitive damages in the

Interpretation of the Food Safety Law of the People's Republic of China, Law Press, 2015, p. 376.

See Zhong Huicheng, "Research on the Punitive Damage Compensation System in the Food Safety Law", Nanchang University Master's Thesis 2016.

10 See Xing Huiqiang: "The United States' Punitive Compensation System for China's Market Supervision Law", Law, 2013, No. 10, p. 46.

11 See $\mathrm{Xu}$ Haiyan: "On the Improvement of the Punitive Compensation System in the Revision of China's Consumer Protection Law", Western Law Review, No. 2, 2013, p. 11.

12 See Wang Liming, "A Study of the Punitive Compensation System in the United States”, Comparative Law Research, No. 5, 2003, p. 9. 
field of food safety fall within the scope of Article 47 of the Tort Liability Law. However, the Food Safety Law and the Tort Liability Law are the have the same level of legal effect. Moreover, the Food Safety Law is both a new law and a special law compared to the Tort Liability Law. Therefore, the Food Safety Law should be applied first.

- Since the Food Safety Law does not stipulate that the application of punitive damages needs to be based on the occurrence of actual damages, if the application of punitive damages in practice increases this requirement, it will make the application of punishment compensation in the field of food safety becomes more difficult, which will encourage a kind of fluke mind of producers or operators, which will also contribute to the immorality of food safety. All of these are contrary to the essence of punitive damages.

- It does not require actual damage, and it can also deter the production and sale of foods that do not meet food safety standards, which is the main function of food safety punitive damages. If actual damage is required, this function will be greatly reduced. ${ }^{13}$

- Due to technical constraints, food has caused some damage to the human body's tissues, but there is a long period of "latency" if it is not detected clinically, or the actual damage caused by eating. Under this circumstance the punitive damages claim must have the consequences of damage, and then the rights of consumers cannot be guaranteed.

\section{DETERMINING MORE FLEXIBLE COMPENSATION STANDARD}

Compared with the Food Safety Law of 2009, the punitive damages clause has increased the damages by three times, the computerized system of multiple compensations, and the minimum amount of compensation, but there are still vague terms and the fixed standard and the "one size fits all" drawbacks do not take into account the reality, resulting punitive damages cannot play its due function. Through the combing of the case, the author finds that the consumer's claim is basically asking the court to support 10 times payment of the compensation price, which will result in a three-fold loss of the provisions too ambiguous; there is no room for its application. Some scholars believe that the content of the responsibilities under Article 2 of the Food Safety Law is that producers or operators should first assume civil liability in accordance with the provisions of the General Principles of the Civil Law, including compensation for consumer medical expenses, nursing expenses, and lost time. Fees, disability living allowances, etc.; if the death is caused, the funeral expenses and the necessary living expenses of the person raised by the deceased shall be paid.

13 See Wang Cheng: "Empirical Inspection of the Ten-Point Penalty Clause of the Food Safety Law", Journal of Beijing Administrative College, No. 5, 2012, p. 15.
At the same time, the consumer has the right to demand punitive damages from the producer or the operator." ${ }^{14}$ The author agrees with this view.

The author believes that the "loss" in the provisions of paragraph 2 of Article 148 of the Food Safety Law includes the price paid, and the "loss" should be interpreted as including "loss of material" and "personal injury". As far as the above is concerned, the situation is as mentioned above. The "price 10 times" and "loss 3 times" stipulated in the second paragraph of the Food Safety Law, in practice, is often applied 10 times the price. Such regulations have drawbacks for the following reasons: first, the amount of compensation should be set in consideration of the interests of consumers, producers and operators, and to some extent it should be inclined to consumers. Since the unit price of the food is generally low, the price of 10 times will not prohibit the phenomenon of producing the food which will not meet the food safety standard from happening. In the case of disability or death compensation, a loss of three times will cause some producers and operators to be overwhelmed, and then resulting in bankruptcy, reorganization or direct closure. Second, at present, the Food Safety Law, as part of the market order regulation law, must promote the development of the economy, protecting consumers, preventing food safety incidents, and preventing high punitive damages from happening. High punitive damage makes enterprises and self-employed households unsustainable. Third, there are various differences between food producers and operators themselves. The one-size-fits-all approach of the Food Safety Law does not take into account the actual situation, which leads to the use of punitive damages are inflexible in judicial practice. It cannot treat differently to achieve substantive justice. Therefore, although China is not a case law country, it should give the referee appropriate discretion in matters involving punitive damages in the Food Safety Law. It can be learned from the experience of the United States. For example, the United States has nine measures for the application of punitive damages, as defined in Article 7 of the US Model Law on Punitive Damages. ${ }^{15}$ And restrictions applicable to punitive damages, including: requirements for bad conduct, higher requirements for certification standards, and restrictions on the amount of punitive damages. Starting from the reality of China, the judge should be given certain discretion, stipulate the factors that the judge should consider when applying punitive damages, and set a lower limit on the

4 Same as 8, pp. 375-376.

15 See Article 7(a) of the US Model Law on Punitive Damages: (1): 1 The nature of the defendant's fault and the impact of the act on the plaintiff and other persons; 2 The amount of compensatory compensation; 3 The defendant has already Any fines, fines, compensation or refunds paid or will be paid; 4 The current or future economic situation of the defendant and the impact of the compensation on his financial situation; 5 The defendant obtained more than this lawsuit through his faulty conduct and The portion of any other compensation or refund for the defendant's lawsuit 6 The effect of the compensation on any other innocent; 7 The remedy done or not done by the defendant after the fault occurred; Or does not meet any applicable standards promulgated by any government agency or other recognized government representative body or organization that has the authority to determine standards based on its functions; 9 Any other factors associated with increasing or decreasing the amount of compensation. 
amount of compensation, and set an upper limit. The amount of the lower limit cannot be too low. The amount of the upper limit cannot be too high and can play a deterrent role. If the upper limit is too high, even if the consumer's judgment as the plaintiff wins the case, it will not be enforced in the judicial practice, but it will bring greater pressure on the implementation work.

\section{CONCLUSION}

Food safety is a major issue concerning the national economy and the people's livelihood. China's Food Safety Law stipulates a punitive damages system. However, there are still many problems in the application of punitive damages clauses, even in the theoretical and practical circles. The applicable requirements are still controversial, and the purpose of the discussion is to reach a consensus. The impeccable wall of food safety has yet to be co-cast by all walks of life, and the future of food safety is expected to be brighter.

\section{REFERENCES}

[1] Gao Shengping. Legislative Purpose and Rule Design of Food Safety Punitive Compensation System [J]. Jurist, 2013 (06): 55-61+47+175.

[2] Zhong Huicheng. Research on Punitive Compensation System in Food Safety Law [D]. Nanchang University, 2016.

[3] Xing Huiqiang. The US Punitive Damages System for the Improvement of China's Market Supervision Law [J]. Law, 2013 (10): 44-50

[4] Xu Haiyan. On the Improvement of the Punitive Damages System in the Revision of China's Consumer Protection Law [J]. Western Law Review, 2013 (02): 8-14.

[5] Wang Liming. Research on the US Punitive Compensation System [J]. Comparative Law Research, 2003 (05): 1-15.

[6] Wang Cheng. An Empirical Study on the Judicial Application of the Tenfold Compensation Clause of the Food Safety Law [J]. Journal of Beijing Administrative College, 2012(05): 14-18 